\title{
The Past Need Not Be Prologue: Why Pessimism about Civic Education Is Premature
}

\author{
Stephen Earl Bennett, University of Cincinnati
}

ike Hindy Lauer Schachter (1998), Ltephen Leonard (1999) warns that scholars who favor the APSA Task Force on Civic Education's goal of educating for an active citizenry should study past failures to achieve this aim. Both urge learning from earlier disciplinary attempts at civic education in order to avoid repeating previous mistakes.

Schachter and Leonard draw different conclusions from the past. Schacter belicves earlier failures to instill civic norms should "spur us on to one more try" (635). Leonard, however, contends the effort will be " "pure futility and waste." " For that reason, I concentrate on his analysis.

We should study our discipline's history. Knowledge of the past improves understanding of the present. Albert Somit and Joseph Tanenhaus ${ }^{2}$ observed that American political scientists were ignorant of the discipline's history, and that they "have paid a heavy price in time, effort, and controversy for their failure to attend more closely to their past" $(1967,3) .^{3}$

That said, two caveats should be noted. First, the past does not automatically reveal itself. Historical facts have to be selected, sorted, and explained, and careful selection of some facets of the past-along with even more careful passing over of others in silence-can create a distorted interpretation of yesterday. Second, writers can draw very different conclusions from the past's lessons. Lconard's pessimism regarding previous disciplinary efforts to instill civic norms is neither the only nor

Stephen Earl Bennett is professor of political science at the University of Cincinnati. His Ph.D. in political science is from the University of Illinois, Urbana-Champaign. Bennett has published books and articles on American political behavior. His research focuses on political communication, youth and politics, and civic education. the best assessment of what the past has to teach.

Leonard makes two major points. First, even though many political scientists sympathize with the ideal of civic education, absent "compelling reasons" for acting on these good intentions, we will witness another failure akin to those following earlier calls for great civic education efforts. Second, success in political science departments, as is true throughout academe, comes to researchers and, in lesser measure, trainers of graduate students.

The crux of Leonard's argument is brutally simple: "How far will excellence in civic education get you when you are trying to get hired, tenured, and promoted? ... If you want to get ahead in academic political science, you don't spend your time engaging in 'civic education.' You spend it on research. The rewards for excellence in civic education are few, far between, and little coveted; the rewards for publication are many, immediate, and so-for many academics-highly significant."

As Leonard sees it, the Task Force faces an impossible task in these "publish or perish" times. Because research and publication are so highly valued and well rewarded, "any disciplinary rededication to civic education will have to await a monumental reconstruction of American academic culture."

Perhaps. But consider this: Trends in enrollments in political science courses and majors in our departments are not favorable (Mann 1999). Moreover, young people are manifesting less and less interest and engagement in politics (Bennett 1996, 1998), possibly because declining civic education in schools has left them less and less prepared to be active citizens (see Janowitz 1983).

Fewer students mean fewer jobs in higher education. Academic administrators pay close attention to data on enrollments/majors, and departments experiencing declining student FTEs are not likely to increase, or even maintain, faculty slots. Anyone who has been reading the APSA's recent reports on academic job placements is aware of the daunting prospects facing new Ph.D.s (Mann 1997, 1998; Mann and Yin 1999; Yin 1998).

Leonard should be careful what he asks for. He may get a discipline that turns its back on civic education, and then finds its initiates facing crimped job prospects. If departments cannot place their Ph.D.s in suitable jobs, a major reason for keeping graduate programs disappears. There are already moves in some states to curtail the number of departments offering doctoral degrees, and one wonders why we would adopt a tactic that might exacerbate those pressures.

Happily, Leonard need not get what he asks for. His assumption of an incompatibility between research and civic education is wrong. Consider just two names: Charles $\mathrm{E}$. Merriam and M. Kent Jennings. Both are past presidents of the American Political Science Association. Moreover, both are connected with major research projects exploring civic education cum political socialization. Jennings' four-decadelong analysis of the high school senior class of 1965 and their parents continues to this day (sec, e.g., Jennings 1987; Jennings and Markus 1984; Jennings and Niemi 1974, 1981; Jennings and Stoker 1999).

It is Merriam, however, to whom I wish to turn, for his contributions to civic education occurred during the period that Leonard and Schachter cover, as Leonard concedes in a note. In spite of or because of his commitment to scientism (Merriam 1970; Somit and Tanenhaus 1967, 110-30), Merriam probably did more for civic education and scholarly research on the topic than any 
other scholar of the $1920 \mathrm{~s}$ and $1930 \mathrm{~s}$ (Merriam 1931, 1934). Beyond his own scholarship, Merriam organized the multivolume Civic Training series that would, along with New Aspects of Politics, be the inspiration for Gabricl Almond and Sidney Verba's seminal The Civic Culture (1963, vii). When one adds his years as a Chicago city alderman and his record of training graduate students, Merriam becomes a "triple threat" in the academy's rotation of research, teaching, and service.

Jennings' and Merriam's careers do not invalidate the observation that calls for greater emphasis on civic education by APSA committees between 1908 and 1922 failed to halt the discipline's increasing emphasis on research and graduate training. As do other social science disciplines (see Bell 1982; Ross 1990), political science resonates with developments in higher education and socicty. It was, for example, the public's declining political engagement during the first third of the twentieth century that motivated APSA's members to worry about civic education (Kleppner 1982; McGerr 1986). Onc can also read the report of the Association's Committee for the Advancement of Teaching (1951), which Leonard rightly believes buttressed the status quo, as reflecting broader tendencies in American socicty. ${ }^{4}$

Jennings and, especially, Merriam illustrate an important point. One can combine interest in civic education with a rich career in political science, including recognition by one's peers as a precminent scholar. Moreover, as pressures build for more involvement in teaching and community service, what better way for a political scientist to meet these demands than by taking part in civic education.

Permit me, in closing, to make several disparate points. First, do not assume that if political scientists eschew civic education nothing of the sort will be done. A number of projects fostering civic education are already under way, some of them by educators with agendas that many political scientists will find odd (e.g., Cogan and Derricott 1998). Others, while marginally controlled by political scientists, focus on what is called "service learning," which is very little different from the experiential learning programs endorsed by early APSA committees that are now viewed as failures (e.g., Battistoni and Hudson 1997). Efforts at civic education will proceed with or without our involvement. I leave it to my disciplinary colleagues to decide which option is preferable.

Second, sooner rather than later someone will point to past studies showing little or no payoff from civic education as a reason for eschewing the Task Force's project. One can readily point to several studies showing little or no benefits derived from taking social studies/political science courses in high school or college (e.g., Langton and Jennings 1968; Somit, Wilke, and Cooley 1958).

Before we decide, however, that there is no evidence that social studies/political science courses contribute to civic education, we would do well to read Richard Niemi and Jane Junn's recent book (1998). In a sophisticated analysis of the topic, Niemi and Junn conclude that civic education courses palpably contribute to young people's understanding of public affairs. We need more research on how young people learn and we need to apply improved un- derstanding of the psychology of learning to designing more effective civic education experiences. Niemi and Junn show that such efforts will pay dividends.

There are some important things that political scientists committed to civic education should do. We must include educators from precollegiate levels in our efforts. The Task Force includes Mary Hepburn, an expert on precollegiate education. I urge the Task Force to bring more of these folks onboard. If we do not involve precollegiate educators in planning civic education projects, we ought not be surprised if they do not "buy in" to proposals we make.

If we really want to improve civic education in primary and secondary schools, political scientists will have to get involved in education at these levels. The Task Force is cstablishing a network of institutes of government and political science departments that have current and emerging programs in civic education, and will also work to alter the academy's reward structure to make civic education an attractive professional pursuit. Like its critics, the Task Force is reading history and trying to avoid earlier mistakes.

Finally, political scientists should lobby state legislators to tighten standards for certifying teachers of government/political science. Currently, many who teach what pass for government/political science courses in primary and secondary schools have almost no collegiate training in political science. Is it asking too much of our colleagues to urge that they take some time to influence a governmental process if the result enhances the discipline? After all, lobbying is worth a line on a vitae.

\section{Notes}

1. As Leonard acknowledges, the phrase is from William Bennett Munro's 1927 APSA Presidential Address. Leonard's rendering of Munro's assertion is troublesome. Leonard has Munro assert that previous disciplinary efforts at civic education were "pure futility and waste." That, however, is not what Munro meant. Munro wrote that moncy spent on "campaigns for the promotion of better citizenship" in the absence of scientific methods to improve understanding of politics was wasted $(1928,7)$. Munro cautioned that naivveté should be avoided, not scientifically grounded training for citizenship.

2. According to Leonard, Somit and Tanenhaus account of the discipline's formative years is "still without rivals" (Leonard 1999, note 1).

3. I wish that Somit and Tanenhaus" endeavor had changed things, but it did not.
The recent publication of essays on the discipline's past suggests that all may not be lost (Farr and Seidelman 1993; Farr, Dryzek, and Leonard 1995; Lindblom 1997; Smith 1997).

4. As Paul Lazarsfeld and Wagner Thielens Jr. (1958) showed, the typical social scientist of the early 1950s was not inclined toward radical reforms. 


\section{References}

Almond, Gabriel A., and Sidney Verba. 1963. The Civic Culture: Political Attitudes and Democracy in Five Nations. Princeton: Princeton University Press.

American Political Science Association, Committee for the Advancement of Teaching. 1951. Goals for Political Science. New York: Sloane.

Battistoni, Richard M., and William E. Hudson, eds. 1997. Experiencing Citizenship: Concepts and Models for Service-Learning in Political Science. Washington, DC: American Association for Higher Education.

Bell, Danicl. 1982. The Social Sciences Since the Second World War. New Brunswick, NJ: Transaction.

Bennett, Stephen E. 1996. "Why Young Americans Hate Politics, and What We Should Do About It." PS: Political Science and Politics 29(March): 47-53.

—. 1998. "Young Amcricans' Indifference to Media Coverage of Public Affairs." PS: Political Science and Politics 31(September): $535-41$.

Cogan, John J., and Ray Derricott, eds. 1998. Citizenship Education for the 21st Century: An International Perspective on Education. London: Kogan-Page.

Farr, James, and Raymond Seidelman, eds. 1993. Discipline and History: Political Science in the United States. Ann Arbor: University of Michigan Press.

Farr, James, John S. Dryzek, and Stephen T. Leonard, eds. 1995. Political Science in History: Research Programs and Political Traditions. New York: Cambridge University Press.

Janowitz, Morris. 1983. The Reconstruction of Patriotism: Education for Civic Consciousness. Chicago: University of Chicago Press.

Jennings, M. Kent. 1987. "Residues of a Movement: The Aging of the American Protest Generation." American Political Science Review 81(June): 367-82.

_, and Gregory B. Markus. 1984. "Partisan Orientations over the Long Haul: Results from a Three-Wave Political Socialization Panel Study." American Political Science Review 78(December): 1000-18.
Jennings, M. Kent, and Richard G. Niemi. 1974. The Political Character of Adolescence: The Influence of Families and Schools. Princeton: Princeton University Press.

- 1981. Generations and Politics: A Panel Study of Young Adults and Their Parents. Princeton: Princeton University Press.

Jennings, M. Kent, and Laura Stoker. 1999. "The Persistence of the Past: The Class of 1965 Turns 50." Presented at the annual meeting of the Midwest Political Science Association, Chicago.

Kleppner, Paul. 1982. Who Voted? The Dynamics of Electoral Turnout, 1870-1980. New York: Praeger.

Langton, Kenneth, and M. Kent Jennings. 1968. "Political Socialization and the High School Civics Curriculum." American Political Science Review 62(September): 85267.

Lazarsfeld, Paul F., and Wagner Thielens Jr. 1958. The Academic Mind: Social Scientists in a Time of Crisis. Glencoe, IL: The Free Press.

Leonard, Stephen T. 1999. "'Pure Futility and Waste': Academic Political Science and Civic Education." PS: Political Science and Politics 32(December)

Lindblom, Charles E. 1997. "Political Sciences in the 1940s and 1950s." In American Academic Culture in Transition, eds. Thomas Bender and Carl E. Schorske. Princeton: Princeton University Press.

Mann Sheilah. 1997. "Placement of Political Science Doctoral Students in 1996: Degrees Matter." PS: Political Science and Politics 30(September): 602-10.

—. 1998. "Finding Jobs in Political Science: 1996 Placement Candidates Report on Their Employment Search and Outcomes." PS: Political Science and Politics 31(September): 591-608.

- 1999. "What the Survey of American College Freshmen Tells Us About Their Interest in Politics and Political Science." PS: Political Science and Politics 32(June): $264-68$.

___, and Jun Yin. 1999. "A Postscript to 'Finding Jobs in Political Science': A Survey of 1996-97 Ph.D.s' Employment
Searches and Outcomes." PS: Political Science and Politics 32(March): 141-46.

McGerr, Michael E. 1986. The Decline of Popular Politics: The American North, 1865-1928. New York: Oxford University Press.

Merriam, Charles E. 1931. The Making of Citizens. Chicago: University of Chicago Press.

- 1934. Civic Education in the United States. New York: Scribner's.

— 1970. New Aspects of Politics. 3rd rev. ed. Chicago: University of Chicago Press.

Munro, William Bennett. 1928. "Physics and Politics-An Old Analogy Revised." American Political Science Review 22(March): 1-11.

Niemi, Richard G., and Jane Junn. 1998 Civic Education: What Makes Students Learn. New Haven: Yale University Press.

Ross, Dorothy. 1990. The Origins of American Social Science. New York: Cambridge University Press.

Schachter, Hindy Lauer. 1998. "Civic Education: Three Early American Political Science Association Committees and Their Relevance to Our Times." PS: Political Science and Politics 31(September): 63135.

Smith, Rogers M. 1997. "Still Blowing in the Wind: The American Quest for a Democratic, Scientific Political Sejence." In American Academic Culture in Transition, ed. Thomas Bender and Carl E. Schorske. Princeton: Princeton University Press.

Somit, Albert, and Joseph Tanenhaus. 1967. The Development of American Political Science: From Burgess to Behavioralism. Boston: Allyn and Bacon.

—, Walter H. Wilke, and Rita W. Cooley. 1958. "The Effect of the Introductory Political Science Course on Student Attitudes Toward Personal Political Participation." American Political Science Review 52(December): 1129-32.

Yin, Jun. 1998. "Placement Report: Political Science Ph.D.s and ABDs on the Joh Market in 1997." PS: Political Science and Politics 31(December): 818-25. 